Stream: Culture/Politics/Technology, 5(1): 37-44

http://journals.sfu.ca/cpt/index.php/stream/index

\title{
The Managing of Peer-to-Peer File Sharing Technologies' Network Effect: An Adaptation of Actor-Network Theory
}

\author{
Kobra Elahifar \\ Department of Communication and Culture, University of Calgary
}

\begin{abstract}
Peer-to-peer (P2P) file-sharing technologies have impacted the music industry, including its strategies for the distribution of the musical products, for more than a decade now. As a result, music labels have delayed full digitization of their industry in fear of "online music piracy". The present paper reviews the historical context of the evolution of the music industry from 1999 to 2012. Using Actor-Network theory, the paper examines the strategies that helped the music industry to translate new actors' effect in order to sustain music labels' business on their path to digitize music distribution. I will discuss the impact of new digital policies and methods of governing online behavior including the business concept of "entrepreneurship" as they may potentially affect the future of public domain within the framework of consumer rights.
\end{abstract}

\section{Keywords}

MP3, peer-to-peer file-sharing technologies, fair use, music industry

\section{Introduction}

The transition to the "information society" has carried along concerns and controversies surrounding intellectual property rights - a notion that has been around since the rise of industrialism in the $18^{\text {th }}$ century (Burrell \& Coleman, 2005). From either a cultural, political or economic perspective, the information society centers on technologies that push for information networks. These networking technologies, in turn, facilitate free flow of information (Castells, 1996). Still, facilitation of access to "copyrighted" information within these networks has been increasingly target to major legal confrontations both in the U.S. as well as in most developed countries around the globe. During this period many legal aspects of consumer rights have been questioned, including the right to "fair use". The consumers' right to fair use was initiated in the U.S. after Sony Corporation won the legal battle against Universal Studios Inc.'s court appeal.

Also known as "Betamax case," the U.S. Supreme Court decided that making copies of artistic works (e.g. musical works, movies or TV shows) for individual use cannot be counted as an example of copyright infringement (Balaban, 2001). This decision was backed by the legal notion that essentially certain goods such as artistic works fall in the category of public goods. Now access to public goods must happen within the public domain with either no or low cost charged in return for access. Still, since mp3 file formats hit the market in 1993, the U.S. music labels have been searching for ways to keep up the marketability of their musical products through taking legal actions, on the one hand, and on the other by looking into new business strategies and models to control the crisis within the music market. After more than a decade-long struggle, the U.S. music labels have become wiser in their dealings with the wide but fractious range of their consumers that have been notoriously labeled as "pirates" (Andersen \& Frenz, 2010).

Following the advent of Peer-to-Peer (P2P) file sharing technologies offered by websites such as Napster, and Gnutella, the Recording Industry Association of America (hereafter RIAA) started filing a myriad of lawsuits against these online services and their customers. These measures were contested by the celebrators of the information age -- supporters of free knowledge flow such as Hipatia (2012), the group "Anonymous", as well as anti-copyright advocates who acknowledged the reality of Web 2.0 (Litman, 2006; Rimmer, 2007). They hailed at an end to the "myth" of 
copyrighted work (Fleitcher, 2008; cited in Tabrizi, n.d.), and sought to discuss the truth behind the liberal notion of copyright ownership (Liang, Mazmdar \& Suresh, 2005). For instance, Kinsella (2008) argued that intellect is not as scarce or as tangible as land or property; intellectual property is a concept invented by the capitalist industrialists avid for added value. Such emerging arguments kept humming behind the massive lawsuits RIAA filed against individuals and only came to a halt after the initial introduction of the Anti-Counterfeiting Trade Agreement treaty (hereafter ACTA) in June 2008 (McBride \& Smith, 2008). ACTA coincided with Megaupload's shut-down in January 2012, the introduction of Stop Online Piracy Act bill (hereafter SOPA) to the U.S. Congress, and the proposal of an "educated response" to users of P2P file sharing technologies before a Denial of Service attack (hereafter DoS).

Based on Actor-Network theory, this paper explores the real impact of the emerging actors within the music market in an effort to explain the evolving efforts of the music industry and its regulatory arm in and outside the United States. Actor-network theory has been chosen as the method of analysis for its power to explain music labels' effort to re-establish a new network through the use of the concept of "copyrighted material". As a material-semiotic method of network analysis, Actor-Network Theory recognizes both human actors and non-human actors as power agents within the hierarchy of power relation. For this paper, the non-human actors include: MP3 file format, personal computer, one-click hosting sites, download soft-ware, etc. Considering the asymmetric nature of the power relations within the network (Law, 1992) helps to explore different phases of the network re-punctualization and re-constitution after the emerging, yet less dominant, actors (including the human and non-human) de-punctualize the dominant meaning hooked into the concept of "copyrighted material".

\section{Research Method}

Many meanings associated with the P2P file sharing technology deserve attention. On the one hand, this technology is often stigmatized and criminalized on the legal front; on the other, it is valorized on the anti-copyright front for initiating a culture of knowledge freedom and sharing. Some economists, moreover, seek to consider its marketing merits, including promotion and access to new consumer niches. To start the analysis, the paper draws on research documents available in different areas related to music market research, business ethics, economics, and law since 2001 to show how music industry strives for sustaining its position in the market with paid services such as Insound, Rhapsody and Apple's iTunes Stores. By doing so, the paper explores the kind of narrative that contributes to the creation of an asymmetry between the old versus the new stakeholders in the music business. The path of exploration of this paper is divided into three distinct periods to demonstrate the historical path built around the MP3 music files and P2P file sharing and the heterogeneous meanings thereof. Each period is different in that narratives reach a new climax in the way the legal controversy around "peer-to-peer file-sharing" is narrated. The contingent cultural and economic consequences of these sets of narrations are relevant to the study as they reveal how the old versus new stakeholders are constructed throughout the period. The paper further discusses these constructs in light of the legal and the marketing strategies that have assisted the music industry in translating the differences mediated within the music business by the new actors.

\section{Napster-phobia: Breaking Rules of Access and Distribution in Music Market}

The major cause behind music labels' initial reaction to websites such as Napster and KaZaa can be interpreted as the fear of a potentially huge market loss. Early legal arguments and market research reveal that record labels had an initial fear of launching a digital music business, and embracing edistribution of musical works. The major stumbling block has been the ease of access to music files 
through the web. The music industry aimed at embracing the digital market while looking for ways to maintain its financial performance (Easley, Michel, \& Devaraj, 2003). A recurrent theme and a basic hypothesis in most research available during this time was the "threat" posed by such new "destructive technologies" (Liebowitz, 2006; Netanel, 2003; Freedman, 2003; Peitz \& Waelbroek, 2004; DeVoss \& Porter, 2006; Shang, Chen \& Chen, 2008). These sites offered non-conventional methods of distribution. Public campaigns explained this kind of reaction as the only way to confront digital violation of the artists' right over the copyrighted material; they explained that the artists would have "no incentive to create" if they were to receive no royalties through their album sales (Boldrin and Levine, 2008).

Despite RIAA's claims to protect the artists' exclusive right to copyright through pushing for the legal cases against music pirating sites, anti-copyright scholar Liman (2006) argued that RIAA's phobia of the new technology related to the fact that its exclusive right of artwork distribution was diminished. This idea took a new dimension immediately after independent economic researchers Oberholzer-Gee and Strumpt (2004) published a study that contradicted the hype mediatized in the news by the RIAA. Their study showed that it was uncertain whether music piracy is a threat to music industry sales because it avails users of free music. This result quickly fueled a debate in the newspapers of that year. The New York Times (2004), for example, called the results "heretical". One seemingly sound argument made by business ethics' scholar Robert F. Easley (2005) on the validity of Oberholzer and Strumpt's result would be that, generally speaking, people are more prone to accept things that go for free, but only a segment of them would accept to purchase the same item(s)..

Hence, the effect of piracy on music markets is arguably unclear (Easley, 2005). Many other factors, such as consumers' socio-economic status and the value that consumers associate with pirated music, are in play as well. Although this finding was not well received initially, it was found to be a deciding factor in accounting for the markets' demands on the creation of a legal digital market in the years to come (see Oberholzer-Gee \& Strumpf, 2007; Peitz \& Waelbroeck, 2006; Edström-Frejman, 2007). However, the promotional power of P2P file sharing networks came to be gradually acknowledged when some independent artists like Radiohead, Chuck D (from the band Public Enemy), and Dispatch had their songs distributed through Napster. They found that the digital platforms offered a suitable venue to reach out to their audience, in contrast to the difficulty in getting radio airplay. The band Wilco, for instance, claimed that P2P file sharing networks worked like radio for promoting albums (see Madden, 2009). Thus, the perceived threat of P2P may have resulted in the music industry and better-known artists' lack of an early appreciation of the promotional function of P2P file sharing tools (Easley, Michel, \& Devaraj, 2003).

\section{Massive Lawsuits: Consumers' Right to Fair Use \& New Businesses' Stakes}

This period started with massive lawsuits against the myriad of "music pirates" (Bhattacharjee, Gopal, Lertwachara, \& Marsden, 2006). These lawsuits brought the music industry to the center of debates around rights to intellectual property distribution and use. New actors questioned the Big Five for their lobbying power both on national and international platforms (Bach, 2004). Four major themes and concurrent actors emerged in the legal arguments and business research during this period.

The lawsuits immediately drew attention to the fact that the hard won consumer rights to fair use in the Audio-Home Recording Act (hereafter AHRA) were now technically diminished (Litman, 2006). Based on AHRA, the legitimate consumer could officially burn, rip, or record a song on tapes, CDs or MP3 players for non-commercial purposes/fair use. With the technical measures taken in copyrighted CDs and DVDs, not only had the fair use provision been taken away from the consumers, but those who broke the encryption (for serial copy or fair use purposes) allegedly committed theft under the Digital Millennium Copyright Act (hereafter DMCA) (Bach, 2004). In 
brief, legitimate consumers' right to fair use had been denied for the purpose of stopping "music pirates" that constituted a fraction of consumers.

DMCA had an undermining effect on consumer's right to enjoy music as a public good in private spaces. This came to public attention as RIAA began suing the holders of IP addresses used by those who listened to unauthorized copyrighted music in the comfort of their bedrooms (Litman, 2006). There were two issues at stake here: DMCA allowed the music industry to control music pirates and everyone else's online behavior, even the legitimate consumers. The implication of this might be that, first, the music industry's exclusive right to ownership of copyrighted material can extend to a right to police everyone's online behavior, authorization to track IP addresses, violating internet users' privacy in the interest of spotting "the pirate" who constitutes a fraction of the public at large (Litman, 2006). Second, the right to use music as a public good, recognized in Intellectual Property Rights, is to a certain degree threatened by the music industry's "legal" efforts to protect its profit margin (Litman, 2006). Under such circumstance, digital rights advocates started making claims for consumers' violated rights to music consumption.

The debates in anti-copyright advocacy also brought up a new issue: the mash-up phenomenon. First distributed through P2P file sharing networks, and immediately going viral among music consumers, mash-up songs (as a concoction of fragments of other musical works) were accused of being a form of copyright infringement and a violation of their initial composers' right to their work's integrity (Rimmer, 2007). Anti-copyright advocates such as Jessica Litman (2006), however, argued that mash-up songs and other sampling uses of music works are exemplary of rights akin to those of the authors of written works to draw on other writers' work provided that they respect citation conventions in the fields of literature and scholarship. It seemed that music labels (e.g. EMI) attempted to target mash-ups' -- initially called "bastard pop" or "booties" (McGranahan, 2010) -appearance on the music market as they were distributed at first through unconventional and illegal channels. However, the music industry soon entered into competition, producing mash-up songs for distribution in legal channels, with licensing fees charged to benefit the industry (Boone, Declerck, \&Van Den Buy, 2011). Hence, the music industry was quick enough to act on the mash-up front and return some profit to its own deep pockets.

In addition, public and legal controversies around RIAA's efforts to file suits targeting online misconduct also raised questions in the fields of business ethics and marketing research. These questions were: what is "piracy"? Who are "pirates"? What characteristics do "pirates" share? Why do people "commit" piracy? And what efforts the RIAA might make in order to deter "piracy" without supplying "pirates" with a substitute digital avenue to share and download songs legally? (see Miller, 2004; Bakkar, 2005; Bounie \& Bourreau, 2005; Leung, 2008; Smith \& Telang, 2010). Basically, these questions aimed at finding out whether the music industry could benefit from the positive externalities of P2P file sharing so that it inveigled power amidst "the gales of creative destruction" (Schumpeter, 1975). Similar to its traditional management system, the music industry started to support the new, dynamic, and non-equilibrium nature of music market competition through focusing on the markets' actual process rather than the equilibrium of market forces.

Thus, the real question regarding the P2P file sharing was: is it a germ to scrub or a term to accept and compete with?

Alrafee and Cronan (2006) have noted that both deterrent and preventive initiatives to stop online piracy have been unsuccessful since the loss of revenues continued in the music industry. Alternatively, they proposed to study the attitudinal factors influencing this behavior to see how unethical "pirates" find their own behavior. Their findings further aligned with Oberholzer and Strumpt (2004), showing that piracy doesn't necessarily affect the music market in terms of lost revenues. They further clarified that most people don't see their behavior as more sampling a product than an act of "piracy" (backing the idea that music is an experience good). Finally they concluded that "the effect of online sharing technologies is largely based on anecdotal journalistic evidence" (Alrafee and Cronan, 2006: 237). They noted that online sampling behavior increases 
word-of-mouth advertising which is a healthy strategy for the music industry to invest in. They advise decreasing sampling costs and point to digital sampling strategies as a way to compete illegal downloading.

The music piracy literature continues to inform the music industry that online music sampling behavior indicates that a) the intrinsic value of the music is more important that its digital availability (See Altman, Wong, \& Rojas-Mora, 2010; Anderson \& Frenz, 2007); b) pirates are mostly young people and among the primary consumers of music; c) the music industry's main target audience thus should be treated as customers (LaRose and Kim, 2006); d) not all their consumers are "hard core pirates" and e) DRM restriction actually impedes consumers' willingness to pay (WTP) for a song (Sinha, Machado, \& Sellman, 2009) and thus DRM-free music, as offered in iTunes since 2007, is a better strategy than preventive measures.

Finally, other businesses have emerged on the evidence of prevalent piracy as well. MP3 designer firms, such as Apple and Sony, can be counted as examples of the burgeoning businesses rising from piracy (Leung, 2008). Further research encourages music marketers to work on changing the attitude of music consumers in terms of the definition of piracy as a theft. They believe that young people's attitude is easy to change (Hill, 2007). A glance at the RIAA's website FAQ section and the International Federation of Phonographic Industry (IFPI) 2012 report furnished proof of the music industry's advancement in seizing digital markets' value and translating such positive externalities (RIAA, 2012; IFPI, 2012). The music industry's decision to stop massive lawsuits is concurrent with the implementation of such marketing and educative strategies by 2009.

\section{Discussion and Conclusion: Educated Response, the Last Straw?}

If you happen to be visiting a P2P file sharing web site for the purpose of downloading copyrighted works, your ISP might warn you against your illegal behavior. It may send out a notice called Educated Response, AKA "three strikes". If you pay no heed to this warning on your fourth visit to such a website, your ISP has the right to decrease your access speed, eventually block your access. Hail to the SOPA and ACTA! There's now a legal way to shop for digital music through numerous pay services and music download websites which offer your favorite songs DRM free, portable on your MP3, or even more convenient, right on your Apple iPhones; there are also online streaming services with "share" tools available to ease your way to listen or watch your favorite songs 24/7 with available free one-month trials, and promotions or "brought to you free by" X advertising company (just like your "good old" TV and radio). Concern with prevalent music piracy and the reverence of intellectual property have provided a cover for continuous surveillance on the internet, but what is at stake? As the anti-copyright advocates argue, and as the evidence indicates, the public good and the right to fair use have again been underserved to address the decline in corporations' sales. The main point here, perhaps, is that the music industry has established a relatively more coherent system of handling distribution and use. This has been achieved through music labels' right to ownership of intellectual property.

However, by accepting the power of entrepreneurship in the digitized culture and realizing that it can serve protecting intellectual property, the decision makings have become more democratized and less corporatized. Embracing new modes of music distribution which encourage the empowering culture of sharing has been core to its strategies to sustain in the market. How did this new control become possible? Has music industry reached punctualization within its network? To answer these questions, one must account for the fact that the old ordering in music industry has most obviously undergone changes, but has reached a certain punctualization in terms of pinning new ways of regulating and establishing its state of affairs. This is only due to the music industry's propensity to be more open to newly technologies by entrepreneurs and entrepreneurship, or, as Schumpeter (1975) has theorized, the music industry's hold of entrepreneurs' destructive 
creativity and innovations. As Nye (2006) argues, "Established market leaders suffer from 'path dependency'... [t] hey are too committed to a particular conception of what their product is. This commitment is embedded in its manufacturing process and endemic in the thinking of its managers. When a major innovation appears, a leading firm understands the technology, but remains committed to its product and its production system" (p. 38). For the music industry this has been true mainly in terms of their emerging modes of distribution, and new business models, partly resulting from the new forms of art and new talents.

The other question fairly linked to the answers given above is to ask whether the asymmetry that ANT theorizes in terms of reification of the music market has taken place or not. The main point here, as discussed, is that music market through its new battle against P2P file sharing has established a truly more coherent system of handling distribution and use by drawing on its right to ownership of intellectual property. Nevertheless, the music industry's decision makings have been made more democratized and less corporatized with the acceptance of the power of entrepreneurship in the digitized culture and the realization that it can serve protecting intellectual property. Embracing new modes of music distribution has been core to the music industry's strategies to sustain in the market as they encourage the empowering culture of sharing, which, in fact, ties the argument to the question probed earlier: the idea of copyrighted material functions as a neoliberal concept. Neoliberalism, as the dominant economic paradigm in the globalized world, works its way through technologies of the selves; it facilitates the economic growth with the aid of disciplinary power while proffering autonomy to the individual subjects. As discussed in the paper, educated response and its instruments in and outside the online world are the mastery of the disciplinary power over time through years of market research and negotiations between music industry's stake holders, U.S. Congress and World Trade Organization.

\section{References}

Al-Rafee, S., \& Cronan, T. P. (2006). Digital piracy: Factors that influence attitude toward behavior. Journal of Business Ethics, 63(3), 237-259.

Andersen, B., \& Frenz, M. (2010). Don't blame the P2P file-sharers: the impact of free music downloads on the purchase of music CDs in Canada. Journal of Evolutionary Economics, 20(5), 715-740.

Bach, D. (2004). The double punch of law and technology: Fighting music piracy or remaking copyright in a digital age. Business and Politics, 6(2), 1-33.

Balaban, D. (2001). Battle of the Music Industry: The Distribution of Audio and Video Works Via the Internet, Music and More, The. Fordham Intell. Prop. Media \& Ent. LJ, 12, 235.

Bhattacharjee, S., Gopal, R. D., Lertwachara, K., \& Marsden, J. R. (2006). Impact of Legal Threats on Online Music Sharing Activity: An Analysis of Music Industry Legal Actions. Journal of Law and Economics, 49(1), 91-114.

Boone, C., Declerck, C. H., Rao, H., \& Van Den Buys, K. (2012). Out of tune: The rise and fall of modernistic music in Brussels, 1919-1939. Poetics, 40(1), 44-66.

Boldrin, M., \& Levine, D. K. (2008). Against Intellectual Monopoly. Cambridge: Cambridge University Press.

Bounie, D., Bourreau, M., \& Waelbroeck, P. (2005). Pirates or Explorers? Analysis of Music Consumption in French Graduate Schools. Telecom Paris Economics, Working Paper No. EC-0501.

Burrell, R., \& Coleman, A. (2005). Copyright exceptions: the digital impact (Vol. 6). Cambridge University Press.

Callon, M. (1986). Some elements of a sociology of translation. The domestication of the scallops and the fisherman of St. Brieuc Bay. In J. Law (Ed.), Power, action and belief (pp. 196-233). London: Routledge \& Kegan Paul. 
Castells, M. (1996). The rise of the network society (Vol. 1) Oxford: Blackwell Publishers.

Danaher, B., Dhanasobhon, S., Smith, M. D., \& Telang, R. (2010). Converting pirates without cannibalizing purchasers: the impact of digital distribution on physical sales and internet piracy. Marketing Science, 29(6), 1138-1151.

DeVoss, D. N., \& Porter, J. E. (2006). Why Napster matters to writing: Filesharing as a new ethic of digital delivery. Computers and Composition, 23(2), 178-210.

Easley, R. F. (2005). Ethical issues in the music industry response to innovation and piracy. Journal of Business Ethics, 62(2), 163-168.

Easley, R. F., Devaraj, S., \& Crant, J. M. (2003). Relating collaborative technology use to teamwork quality and performance: An empirical analysis. Journal of Management Information Systems, 19(4), 247-268.

Edström-Frejman, A. (2007). E-Commerce Rhetoric and Reality in the Music Industry: Estimating the Real Impact of File-Sharing Activities on CD-Sales. Media technology and graphic arts, School of computer science and communication, Royal institute of technology (KTH).

Fleischer, Rasmus (June 2008). The Future of Copyright. CATO Unbound, in F.M. Tabrizi, Infromation Will Be Free (2008), retrieved Dec. 4, 2012, from http://www.cs.rutgers.edu/ rmartin/teaching/fall08/cs552/position-papers/015-01.pdf

Freedman, D. (2003). Managing pirate culture: Corporate responses to peer-to-peer networking. International Journal on Media Management, 5(3), 173-179.

Hipatia (2012). Second Manifesto: the right to freedom of knowledge, retrieved Dec. 2, 2012, from http://www.hipatia.info/index.php?id=manifesto2 en

Hill, C. W. (2007). Digital piracy: Causes, consequences, and strategic responses. Asia Pacific Journal of Management, 24(1), 9-25.

Kineslla, N.S. (2008). Against Intellectual Property. Auburn: Alabama, Ludwig von Mises Institute, retrieved Nov. 3, 2012, from http://mises.org/books/against.pdf

LaRose, R., \& Kim, J. (2006). Share, steal, or buy? A social cognitive perspective of music downloading. CyberPsychology \& Behavior, 10(2), 267-277.

Latour, B. (1999). Pandora's hope: essays on the reality of science studies. Harvard University Press.

Law, J. (1992). Notes on the theory of the actor-network: ordering, strategy, and heterogeneity. Systemic Practice and Action Research, 5(4), 379-393.

Leung, T. C. (2008). Should the Music Industry Sue Its Own Customers? Impacts of Music Piracy and Policy Suggestions. University of Minnesota, retrieved Nov. 28, 2012, From http://ihome.ust.hk/ fnjuwong/paper/i-Podandpiracy.pdf

Liang, L., Mazmdar, A., and Suresh, M. (Feb, 2005) Copyright/Copyleft: myths about copyright. Countercurrents, retrieved Dec. 4, 2012, from http://www.countercurrents.org/hrsuresh010205.htm

Liebowitz, S. J. (2006). File Sharing: Creative Destruction or Just Plain Destruction. Journal of Law and Economics, 49(1), 1-28.

Litman, J. (2006). Digital copyright. Retrieved Nov. 20, 2012, from http://works.bepress.com/jessica litman/5

Oberholzer-Gee, F., \& Strumpf, K. (2007). The effect of file sharing on record sales: An empirical analysis. Journal of Political Economy, 115(1), 1-42.

Netanel, N. (2003). Impose a noncommercial use levy to allow free peer-to-peer file sharing. Harvard Journal of Law \& Technology, 17.

Madden, M. (2009). The state of music online: Ten years after Napster. Pew Internet \& American Life Project.

McGranahan, L. (2010). Bastards and Booties: Production, Copyright, and the Mashup Community. Trans: Transcultural Music Review = Revista Transcultural de Música, (14), 8-1.

Miller, B. J. (2004). War against Free Music: How the RIAA Should Stop Worrying and Learn to Love the MP3, The. U. Det. Mercy L. Rev., 82: 303. 
Rimmer, M. (2007). Digital copyright and the consumer revolution: hands off my iPod. Edward Elgar Publishing.

Peitz, M., \& Waelbroeck, P. (2006). Why the music industry may gain from free downloading-the role of sampling. International Journal of Industrial Organization, 24(5), 907-913.

Peitz, M. \& Waelbroek, P. (2004). The effect of internet piracy on music sales: cross-section evidence. Review of Economic Research on Copyright Issues, 1(2): 71-79.

Schumpeter, J. A. (1975). Capitalism and democracy. Harper torchbooks.

Sinha, R. K., \& Mandel, N. (2008). Preventing digital music piracy: The carrot or the stick? Journal of Marketing, 72(1), 1-15.

Smith, M. D., \& Telang, R. (2010). Piracy or promotion? The impact of broadband Internet penetration on DVD sales. Information Economics and Policy, 22(4), 289-298. 